\title{
An Analysis of Blackboard as a Service System
}

\author{
Alaa Moued Alharthi \\ King Abdulaziz \\ University \\ Faculty of Computing \\ and Information \\ Technology- IS \\ Department
}

\author{
Azrilah Abdul Aziz \\ Assistant Professor \\ King Abdulaziz \\ University \\ Faculty of Computing \\ and Information \\ Technology- IS \\ Department
}

\author{
Salha Abdullah \\ Assistant Professor \\ King Abdulaziz \\ University \\ Faculty of Computing \\ and Information \\ Technology- IS \\ Department
}

\author{
Walaa Saleh \\ Alhabashi \\ King Abdulaziz \\ University \\ Faculty of Computing \\ and Information \\ Technology- IS \\ Department
}

\begin{abstract}
To date, there is a remarkable transformation of the economy into service system to facilitate collaboration between customers and service providers, and also to create value through interconnected service enterprises. This paper introduces a literature review on the concepts of service science, service system, and SSME. It describes a service system framework developed by Sophrer and applied it to a university Blackboard system.
\end{abstract}

\section{General Terms}

Service science.

\section{Keywords}

Service science, SSME, services, service systems, web services, Blackboard system.

\section{INTRODUCTION}

Service science began as a "call to action" focusing academics, businesses, and governments on the need for research and education in areas related to service" [1]. Services depend critically on people, technology, and cocreation of value; by using technology people work together to produce value to customers [2].

Most of the learning institutions are moving toward electronic learning technology. E-learning systems offer for instructor and learner different tools for learning and assessment. The teacher can manage courses, content, assessment and reports. The student can view the content of the courses, do the assignment and quizzes, and collaborate in virtual classes. Therefore, Learning Management Systems (LMS) are considered as centralized systems, because they provide the learner with content and information that has been offered by the instructor [3].

Employing the service science and web services technology in e-learning system will facilitate the interaction between different e-learning applications and learning service providers.

This paper analyzes Blackboard system, which applied in one of the universities in Saudi Arabia and examined how the Blackboard system uses a service science framework to facilitate the interaction between students and instructors. The technique used for modeling the system is IDEF0. The Sophrer [4] ten foundational principles will be used to characterize Blackboard as a service system.

\section{PROBLEM STATEMENT}

The main purpose of this paper is to analyze the Blackboard system with framework proposed by Spohrer, et al. (2008), which is one of the frameworks in service science and to identify that the blackboard is a service system.

\section{LITERATURE REVIEW}

Vossen and Westerkamp [5] stated that the problem with standard e-learning system is the flexibility. They found a solution by building a system named LearnServe. This system is based on e-learning area and web services. The system is a collection of activities or processes that provides different courses, and the learner receives checklists that describe the content of them. Based on these checklists, the learners can freely choose the content from various providers that considered web services.

Guoshi Wu and Yiran Wang [6] added that the difficulty of resources sharing and searching is the problem with the existed e-learning system. They suggested designing a prototype that will apply Web services technology to elearning. It presents a service-oriented intelligent e-learning architecture prototype where the learning resources are well defined and is presented by ontology and information exchanging is supported by web services.

Aguirre, et al. [7] has focused in their paper in joint degree (a type of academic degree offered through of e-learning system) and how it could be developed in the heterogeneous elearning system. The work aimed to allow e-learning systems to be able to work in a collaborative way with other universities to make the joint degree possible in e-learning platforms. It proposed the design of a service-oriented architecture, which, through collaboration agreements, will permit the interoperability of functionalities. The suggested architecture is implemented based on web services. The architecture allows the e-learning system to be able to work in a cooperative way by combining their data and functionality through the integration of their services. Finally, they defined a joint degree as an academic program, made up of a cluster of services that offered by the universities through their elearning system.

FAN Baiquan [8] discussed the idea of having architecture supported by web services that offer communication between different software applications on different platforms, to provide interoperability between them. He examined and surveyed different architectures and models for e-learning system and web service and present their characteristics and functionality in connecting different e-learning system through the interaction between the web service agents in each system. 


\section{BACKGROUND OF THE TOPIC 4.1 Service Science, Management, and Engineering}

SSME stands for Service Science, Management, and Engineering. Sophrer et al. [1] defined SSME as "the application of normative service science"; normative service science is the benefit of applying resources of one system for another system. In addition, Maglio et al. [2] defined SSME as "the application of scientific, management, and engineering disciplines to tasks that one organization beneficially performs for and with another".

There are two purposes of SSME. Firstly, according to Chesbrough et al. [9] is "to understand how an organization can invest effectively to create service innovations and to realize more predictable outcomes". Secondly, as stated by Maglio et al. [2] which is "aims to understand and catalog service systems, and apply that understanding to advancing our ability to design, improve, and scale service systems for practical business and societal purposes (efficiency, effectiveness, and sustainability)".

\subsection{Service Science}

Service Science is a new way to economic exchange. IBM has developed a definition of the service science concept as "an interdisciplinary approach to the study, design, implementation, and innovation of service systems". Service was driven from "The idea of creating a science of service arose several years ago, as business and academia began to discover that service marketing is the most economic activity" Zeithaml et al. [10]. Moreover, Sophrer et al. [11] had defined service science as "the study of the application of the resources of one or more systems for the benefit of another system in economic exchange". The other definition by Katzan [12] that service science is "a collection of models of sub-disciplines abstracted from the service universe, in much the same manner that the physical sciences are collections of sub-disciplines". Tracy and Lyons [13] defined service science as "an emerging multidisciplinary field concerned with the study of service systems and value co-creation".

The service science primary objective is to study value cocreation through service system entities interaction. The development of models used for service system is a challenge and the basic of service science. Service science is integrating human and organizational understanding with technological and business understanding. The purpose of service science is innovating services and gains the ability to scale, design, and improve service system.

\subsection{Services}

Many authors and researchers have defined Service. Stephen, L. \& Vargo, F. [14] defined service as "the application of specialized competences (operant resources, knowledge and skills), through deeds, processes, and performances for the benefit of another entity or the entity itself" based on the Service-Dominant Logic which defined it as "the applications of competencies (knowledge and skill) for benefit of a party". Spohrer and others [11] have described service as "a type of interaction between particular kind of entities aimed at particular outcomes, specifically value co-creation outcomes". Katzan [12] has given the service number of definitions such as:
- An action performed by one person or group on behalf of another person, organization, or group.

- A generic type of action, such as a medical service or a web service.

- The result of an action typically a change is affecting an object or person.

- An organization is behaving in a prescribed way to benefit or operate in the best interests of a person or group.

All researchers agreed that service was the action performed to share benefit and knowledge between entities such: persons, organizations or systems.

\subsection{Service System and Web Services}

Service systems have defined as "collections of resources that can create value with other service systems through shared information" [15]. Besides, Katzan [12] describe service system as "a collection of resources, economic entities, and other services capable of engaging in and supporting one or more service events". However, Maglio and others [2] represent service systems as value creation correlations consist of people, technology, and organizations. Service System is a value producing through aggregation of people, technology, internal and external service systems, which shared information [2].

Web service is about an integration of different existing application or software based on specified criteria by exchanging the data and information between them through the Internet [16]. Web service is a stand-alone software system, which designed to allow interaction between application programs over the Web [3].

\subsection{Blackboard System}

The Blackboard system has many platforms like Blackboard Connect, Blackboard Transact, Blackboard Analytics, Blackboard Mobile, Blackboard Engage, and Blackboard Learn [17]. In this paper, Blackboard Learn Platform will be analyzed. The Blackboard Learning System is a virtual learning environment. It is a Web-based software that provides course management, specified and customized architecture and design, and integrating with student information systems [17]. It provides different functions to users for communication and content sharing. The functions includes [18]:

\section{Communication}

- Announcements: Instructors or faculty member can post announcements for students to read.

- Discussion Board: Allows students and instructors to create discussion threads and reply to them.

- Mail: Allows students and instructors to send emails to one another within the system and external Email.

- Chat: Allows students and instructors to chat in real time with other students in their virtual classroom.

2. Content

- Course content: Allow instructors to post lecture materials, documents, assignments, photos, videos and more.

- Calendar: Instructors can use it to post important dates like assignments submission and exams. 
- Learning modules: Allow instructors to post various online classes or lessons for students to access.

- Assignments: Allows instructors to post assignments and students submit them online.

- Assessments: Allows instructors to post quizzes and exams and allows students to access them online.

- Grade Book: Instructors can post grades on the system, and students can view them.

To move toward blending learning, one of the largest universities in Saudi Arabia has implemented Blackboard system that allows different ways of communication between students and teachers through a virtual classroom, discussion board, announcement and more. It provides online activities such as quizzes, exams, and assignments.

The Blackboard system is currently integrated with ODUS system, which stands for On Demand University System. ODUS is considered as a student information system. ODUS is one type of Software as a Service (SaaS) application, and it is a Web-based application. ODUS application is used to manage instructors and students data.

\section{METHODOLOGY}

The data gathering techniques used are walkthrough and selfstudy methods. The information that had been collected is on Blackboard system, modules in the system, and the other entities and systems that interact with university's Blackboard system.

\subsection{System Modeling}

To analyze the Blackboard system against the selected Sophrer's framework, the functions, and the process of the system must be clarified. The technique used to model the system functions and processes is IDEF0 (Integration Definition for Function Modeling) [19]. IDEF0 is used to produce a function model, which represents the functions, activities or processes inside the modeled system.

IDEF0 was chosen because it is one of the best techniques to describe system functions from top-level view. Figure1 presents the general basic functions of university Blackboard system.

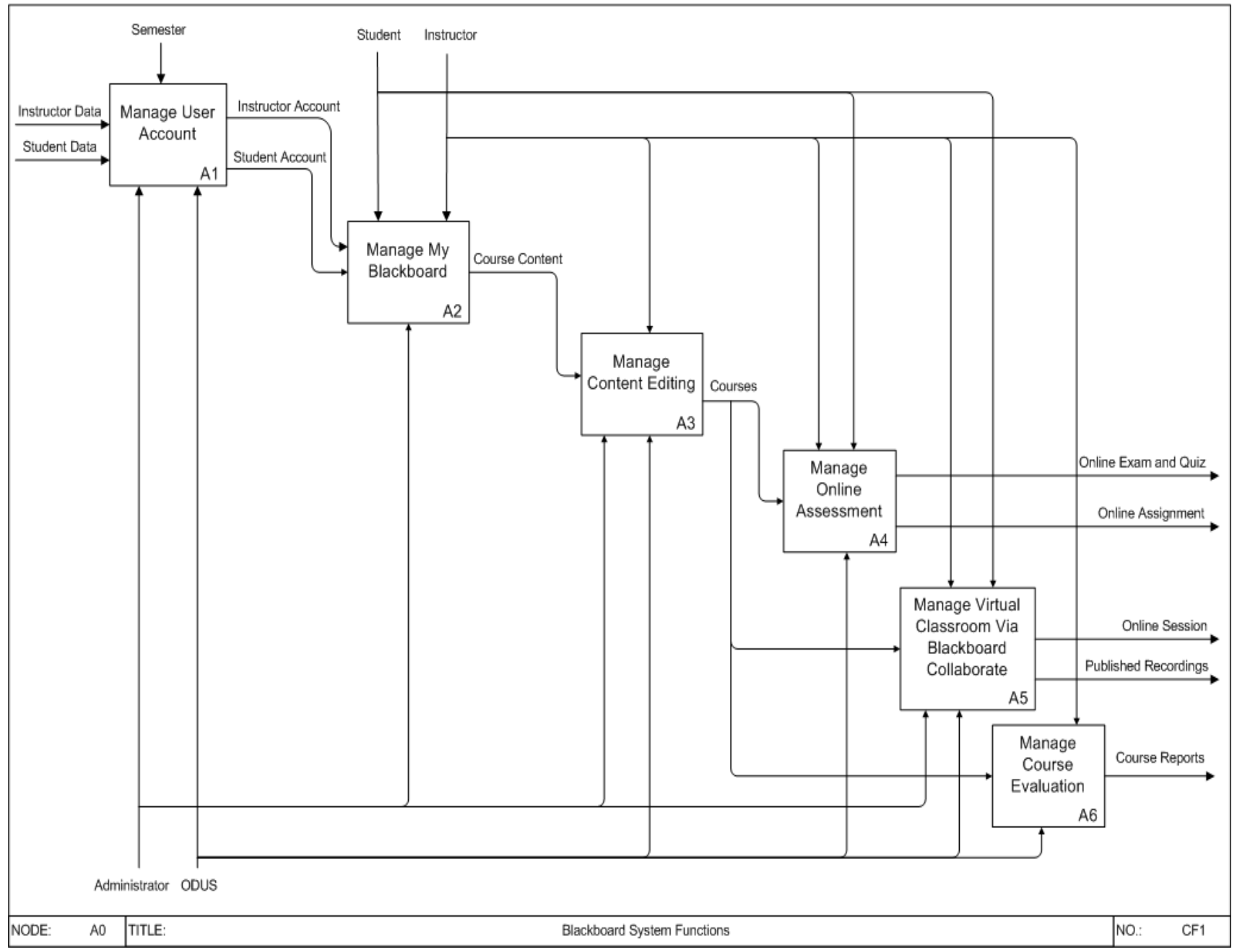

Figure1: Blackboard System IDEF0

\section{ANALYSIS AND MEASUREMENT}

\subsection{Service System Framework}

The ten foundational principles framework of a service system, which is proposed by Spohrer, Anderson, et al. [4], is presented in Figure 2. The explanation of the framework that will be used to identify and categorize Blackboard system as a service system is as below. The ten principles are as the followings. 
1- Resources: Everything useful can be a resource.

2- Entities: Some resources, which can create actions.

3- Access Right: Everything deals with resources access or usage either legal or social.

4- Value Co-Creation Interactions: The contract and promises that entities agree on it because they believe will realize value co-creation.

5- Governance Interactions: A kind of value proposition among a population of governed and authority service system entity.
6- Outcomes: Value co-creation is the outcome when service system entities interaction.

7- Stakeholders: Customer, provider, authority, and competitor are the primary types of stakeholders.

8- Measures: Quality, productivity, compliance, and sustainable innovation are the primary types of measures.

9- Networks: the interaction via value propositions between service systems entities.

10- Ecology: The macro- scale interactions of the populations of different types of service system entities.

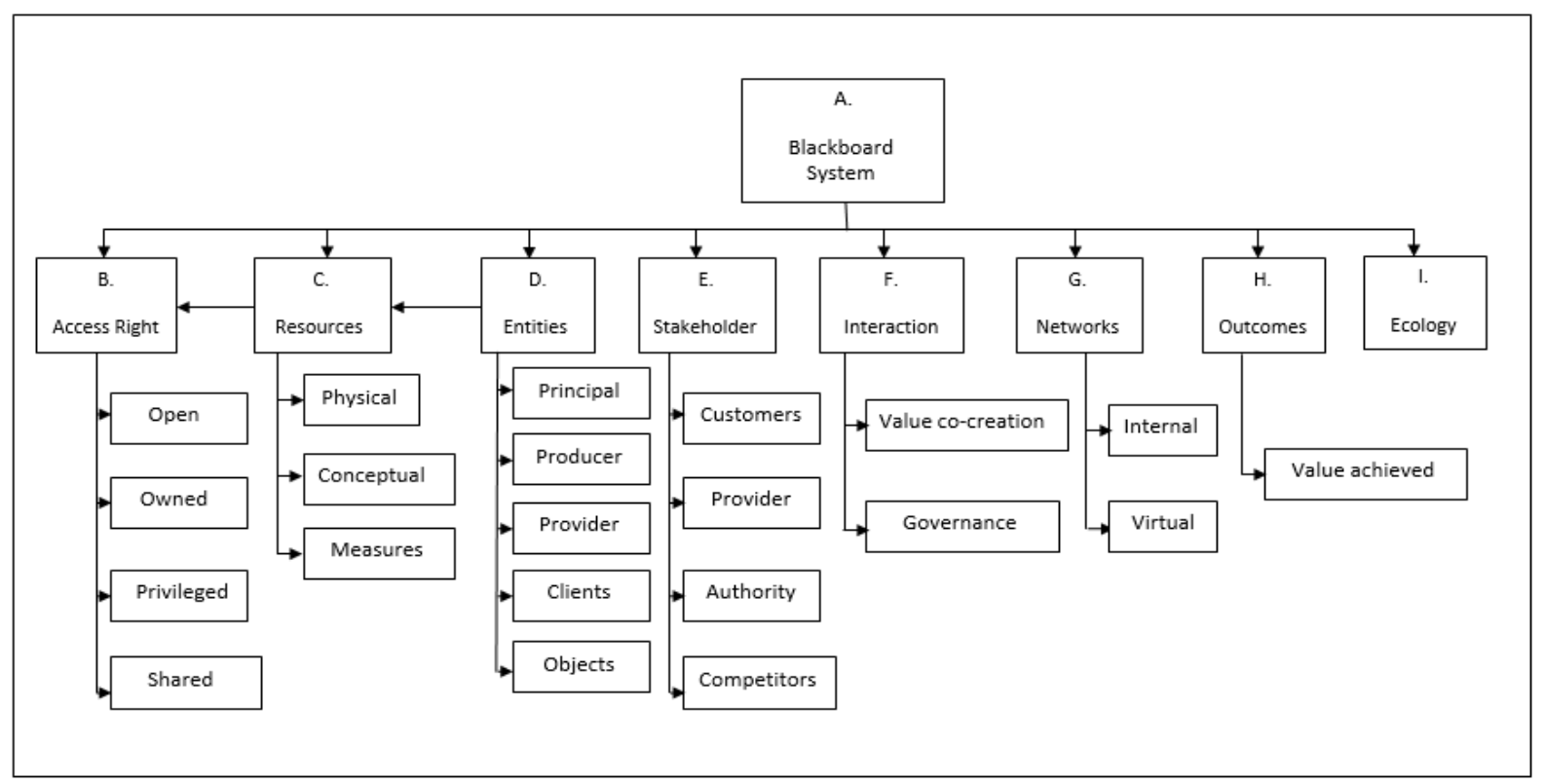

Figure 2: Service System Framwork

\subsection{Applying Service System Framework}

Based on the applied framework and collected data, the characteristics of Blackboard as service system are given as follows:

Table 1: Blackboard System Characteristics

\begin{tabular}{|c|cl|}
\hline Principles & \multicolumn{1}{|c|}{ University Blackboard System } \\
\hline Resources & $1-$ & $\begin{array}{l}\text { Physical: administration staff, } \\
\text { students, instructors, computers, } \\
\text { laptops, smartphone, servers, and } \\
\text { faculties. }\end{array}$ \\
2- & $\begin{array}{l}\text { Conceptual: website, digital content } \\
\text { (video, audio, images), lectures, } \\
\text { exams, homework, quizzes, ideas, } \\
\text { policies, information, knowledge. }\end{array}$ \\
& $3-\begin{array}{l}\text { Measures: instructors and students } \\
\text { feedback, usage statistics. }\end{array}$ \\
\hline Access Rights & $1-$ & $\begin{array}{l}\text { Open materials. } \\
\text { Owned: computers, laptops, and } \\
\text { smartphone. } \\
\text { Privileged: accounts, tabs, modules, } \\
\text { and tab groups. } \\
\text { Shared: course content and } \\
\text { enrollments. }\end{array}$ \\
\hline
\end{tabular}

\begin{tabular}{|c|c|}
\hline Entities & $\begin{array}{ll}\text { 1- } & \text { Principal: University. } \\
\text { 2- } & \text { Producer: Blackboard Inc. } \\
\text { 3- } & \begin{array}{l}\text { Provider: Deanship of E-Learning } \\
\text { and Distance Education at the }\end{array} \\
& \begin{array}{l}\text { University, instructor. } \\
\text { 4- }\end{array} \\
\text { Clients: instructors, students, } \\
\text { administration staff, IT support. } \\
\text { 5- } \begin{array}{l}\text { Objects: lectures, exams, homework, } \\
\text { quizzes, discussion and rating. }\end{array}\end{array}$ \\
\hline Stakeholders &  \\
\hline Interactions & $\begin{array}{l}\text { 1- } \begin{array}{l}\text { Value co-creation interactions: } \\
\text { administration staff interactions, } \\
\text { instructors' interactions, and } \\
\text { students' interactions. } \\
\text { 2- } \\
\text { Governance interactions: Blackboard } \\
\text { company contract, university, and }\end{array} \\
\end{array}$ \\
\hline
\end{tabular}




\begin{tabular}{|c|c|}
\hline & faculties. \\
\hline Network & $\begin{array}{ll}\text { 1- } & \text { Internal: regular students, distance } \\
\text { education students, affiliation } \\
\text { students, administration staff, } \\
\text { instructors, faculties, and university. } \\
\text { 2- } & \text { Social Network like Facebook, } \\
& \text { Twitter, Email, Blogs, and YouTube. } \\
\text { 3- } & \text { Virtual: online virtual classroom via } \\
& \text { Blackboard Collaborate. }\end{array}$ \\
\hline Outcomes & 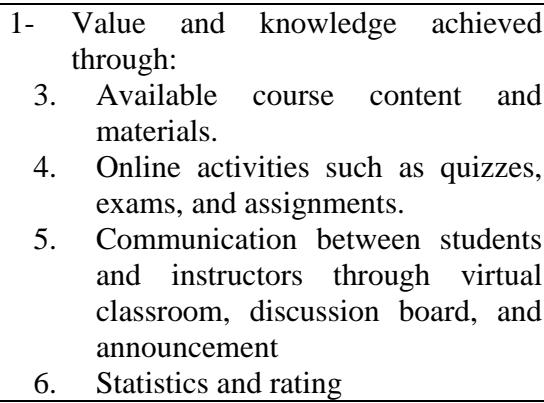 \\
\hline Ecology & $\begin{array}{l}\text { Provides a blended learning environment } \\
\text { and course management and provides } \\
\text { users with a platform for communication } \\
\text { and sharing content. }\end{array}$ \\
\hline
\end{tabular}

By comparing to the principles of the framework, Blackboard LMS is compatible with most of the principles of science services. As a result, Blackboard LMS achieves the knowledge and value through the provided education services and instrument. Therefore, Blackboard can be categorized as a service system.

\section{CONCLUSION}

This paper present several definitions and explanations for service science, Service Science Management and Engineering (SSME), service and service systems and web services. Service science or SSME are intended to recognize and characterize service systems. Moreover, service systems are interacting to co-create and produce knowledge and value. Blackboard system is categorized based on Spohrer's ten foundational principles to characterize it as a service system. Blackboard fulfills knowledge and value through the provided online facilities and services.

There are several methods and framework to implement service science; Spohrer framework is one of them, which has been used to categorize the service system. In the future for more accuracy, other frameworks could be applied to evaluate the system like Service-Dominant (S-D) Logic Framework [11].

\section{REFERENCES}

[1] Spohrer, J., \& Maglio, P. P. (2010). Service science: Toward a smarter planet. Introduction to service engineering, 3-30.

[2] Maglio, P. P., Srinivasan, S., Kreulen, J. T., \& Spohrer, J. (2006). Service systems, service scientists, SSME, and innovation. Communications of the ACM, 49(7), 81-85.

[3] Vossen, G., \& Westerkamp, P. (2004). Maintenance and exchange of learning objects in a web services based elearning system. Electronic Journal of e-Learning, 2(2), 292-304.

[4] Spohrer, J., \& Kwan, S. K. (2008). Service science, management, engineering, and design (SSMED): Outline
$\&$ references. The future of services: Trends and perspectives, 1, 232.

[5] Vossen, G., \& Westerkamp, P. (2003, July). E-learning as a Web service. In Database Engineering and Applications Symposium, 2003. Proceedings. Seventh International (pp. 242-249). IEEE.

[6] Wu, G., \& Wang, Y. (2011). Research on e-learning system prototype based on semantic web service technology. In Computing and Intelligent Systems (pp. 247-254). Springer Berlin Heidelberg.

[7] Aguirre, S., Salvachúa, J., Quemada, J., Fumero, A., \& Tapiador, A. (2006, November). Joint degrees in elearning systems: a web services approach. In Collaborative Computing: Networking, Applications and Worksharing, 2006. Collaborate Com 2006. International Conference on (pp. 1-5). IEEE.

[8] FAN Baiquan. (2004). Web Services Applied to ELearning Systems.

[9] Chesbrough, H., \& Spohrer, J. (2006). A research manifesto for services science. Communications of the ACM, 49(7), 35-40.

[10] Zeithaml, V. A., Parasuraman, A., \& Berry, L. L. (1985). Problems and strategies in services marketing. The Journal of Marketing, 33-46.

[11] Spohrer, J., Anderson, L., Pass, N., \& Ager, T. (2008, December). Service science and service-dominant logic. In Otago Forum (Vol. 2, pp. 4-18).

[12] Katzan, H. (2011). Principles of service systems: An ontological approach. Journal of Service Science (JSS), 2(2), 35-52.

[13] Lyons, K., \& Tracy, S. (2013). Characterizing organizations as service systems. Human Factors and Ergonomics in Manufacturing \& Service Industries, 23(1), 19-27.

[14] Stephen, L. \& Vargo, F. (2008). Why "service"? In CONCEPTUAL/THEORETICAL PAPER.

[15] Spohrer, J., Vargo, S. L., Caswell, N., \& Maglio, P. P. (2008, January). The service system is the basic abstraction of service science. In Hawaii International Conference on System Sciences, Proceedings of the 41st Annual(pp. 104-104). IEEE.

[16] Cavanaugh, E. (2006). Web services: Benefits, challenges, and a unique, visual development solution. White paper, Feb 10

[17] Paul Muljadi (2011). E-Learning: Overview and Topics.

[18] El Zawaidy, H. A. Z. H. (2014). Using Blackboard in online learning at Saudi universities: faculty member's perceptions and existing obstacles. International Interdisciplinary Journal of Education, 3(7), 145-154.

[19] PUBS, F. (1993). Announcing the standard for integration definition for function modeling (idef0). Draft Federal Information Processing Standards Publication, 183.

[20] Tracy, S., \& Lyons, K. (2013). Service systems and the social enterprise. Human Factors and Ergonomics in Manufacturing \& Service Industries, 23(1), 28-36. 
[21] Arto, W. (2013). Three complementary perspectives in service science: service-dominant logic, systems thinking, and service design. In Highlights in service research. Retrieved March 15, 2015

[22] Gruhl, D., Bailey, J., Spohrer, J., \& Maglio, P. P. (2007). Steps toward a science of service systems. Computer, (1), 71-77.

[23] Razek, M. A., \& Mashat, A. S. (2014). Towards More Efficient Semantic Web-Services Using Cloud Interoperability. Pensee, 76(11).
[24] Roelens, B., Lemey, E., \& Poels, G. (2012). A service science perspective on business modeling. In Proceedings of the 6th International Workshop on Value Modeling and Business Ontology (p. 8).

[25] Vargo, S. L., Maglio, P. P., \& Akaka, M. A. (2008). On value and value co-creation: A service systems and service logic perspective. European management journal, 26(3), 145-152.

[26] Vossen, G., \& Westerkamp, P.(2008). Can ServiceOrientation Make E-Learning Standards Obsolete?. 